ISSN : $1979-7362$

\title{
Analisis Jenis dan Tingkat Serangan Hama dan Penyakit Pada Tanaman Padi Menggunakan Alat Spektrometer
}

\author{
Evi Astriah ${ }^{1}$, Daniel ${ }^{1}$ dan Totok Prawitosari ${ }^{1}$
}

Program Studi Teknik Pertanian, Universitas Hasanuddin Makassar

\begin{abstract}
ABSTRAK
Hama dan penyakit merupakan salah satu resiko yang harus dihadapi setiap usaha pembudidayaan tanaman padi. Adanya serangan hama dan penyakit dapat menjadi faktor terjadinya penurunan hasil tanaman padi. Dengan kemajuan teknologi, petani dapat meningkatkan hasil produksi tanaman padi. Salah satu intrumen teknologi yang dapat digunakan yaitu spektrometer. Alat ini dapat mengukur spektrum benda berdasarkan cahaya yang terpantulkan dan menghasilkan panjang gelombang. Tujuan penelitian ini untuk mendeteksi tingkat serangan hama dan penyakit tanaman padi dengan alat spectrometer untuk menentukan panjang gelombang yang spesifik dalam penentuan tingkat serangan hamadanpenyakittanaman. Metode yang digunakan adalah menganalisis kondisi tanaman padi yang terserang hama/penyakit, menggunakan alat spektrometer dengan pengolahan data menggunakan software spektrawiz berdasarkan nilai kanal blue, green, red, dan NIR yang dihasilkan. Hasil yang diperoleh yaitu untuk varietas dengan serangan hama putih memiliki nilai NDVI $\mathrm{R}^{2}$ maksimum yautu 0,968 , nilai $R V I \mathrm{R}^{2}$ maksimum yaitu 0,829 , dan NDRE $\mathrm{R}^{2}$ maksimum yaitu 0,994 . Varietas dengan serangan hama penggerek batang memiliki nilai NDVI $\mathrm{R}^{2}$ maksimum yautu 0,955 , nilai $R$ VI $\mathrm{R}^{2}$ maksimum yaitu 0,994 , dan NDRE $\mathrm{R}^{2}$ maksimum yaitu 0,829 . Varietas tanaman padi yang tidak terserang hama tertentu (hama putih dan hama penggerek batang) memiliki nilai NDVI $\mathrm{R}^{2}$ maksimum yautu 1 , nilai RVI $\mathrm{R}^{2}$ maksimum yaitu 0,89 , dan NDRE $\mathrm{R}^{2}$ maksimum yaitu 0,997 .
\end{abstract}

Kata Kunci: Tanaman Padi, Hama/Penyakit, Spektrometer

\section{PENDAHULUAN}

\section{Latar Belakang}

Dalam pembudidayaan tanaman padi banyak hal yang perlu di perhatikan agar taman padi dapat menghasilkan banyak bulir padi dan memiliki kualitas yang baik. Salah satu faktor yang dapat mempengaruhi penurunan produktivitas padi adalah adanya serangan hama pada tanaman padi. Serangan hama dan penyakit merupakan resiko yang harus dihadapi dan diperhitungkan dalam setiap usaha budidaya tanaman. Resiko ini merupakan konsekuensi dari setiap perubahan ekosistem sebagai akibat budidaya tanaman yang dilakukan.Sedangkan ketidakpastian iklim merupakan suatu hal yang harus diterima sebagai fenomena alam.Perubahan atau ketidak pastian iklim sangat berpengaruh terhadap perkembangan hama/penyakit dan juga berpengaruh langsung terhadap usaha budidaya tanaman. Faktor lain yang berpengaruh terhadap produksi tanaman adalah faktor lingkungan (curah hujan, suhu, musim, dan kelembaban udara), juga biaya produksi seperti bibit, pupuk dan sebagainya.

Kemajuan teknologi dapat mendukung budidaya tanaman padi sehingga dapat meningkatkan produksi padi.Salah satu instrument teknologi adalah spektrometer, yang dapat digunakan untuk mengukur spektrum dari suatu benda berdasarkan cahaya yang terpantulkan dan menghasilkan suatu panjang gelombang.Cara kerja spektrometer adalah dengan melakukan analisa panjang gelombang cahaya.Software yang digunakan adalah spektrawiz yang merupakan software untuk mengolah data yang telah di ambil menggunakan spektrometer dalam bentuk grafik yang 
memperlihatkan pancaran gelombang yang dihasilkan oleh serangan hama yang terdapat pada tanaman padi.

Penelitian ini dilakukan agar dapat mendeteksi adanya serangan hama/penyakit pada tanaman padi dengan cara mengetahui reflektansi cahaya yang terdapat pada tanaman padi yang terserang hama/penyakit dengan menggunakan alat spektrometer.

\section{Tujuan dan Kegunaan}

Penelitian ini bertujuan untuk mendeteksi tingkat serangan hama dan penyakit tanaman padi dengan alat spektrometer untuk menentukan panjang gelombang yang spesifik dalam penentuan tingkat serangan hama dan penyakit tanaman.

Kegunaan dari penelitian ini yaitu sebagai sumber informasih akan adanya serangan hama pada tanaman padi, sehingga dapat menghindari penurunan produktivitas.

\section{TINJAUAN PUSTAKA}

\section{Tanaman Padi}

Padi (Oryza sativa L.) termasuk dalam tanaman pangan rumput berumpun.Sejarah menunjukkan bahwa penanaman padi di Zhejiang (Cina) sudah dimulai ada 3.000 tahun SM. Bukti lainnya penemuan fosil butir padi dan gabah ditemukan di Hanstinapur Uttar Pradesh India sekitar 100-800 tahun SM (Assor, 2015).

\section{Varietas Tanaman Padi}

a. Varietas Inpari 23

Varietas Inpari 23 ditemukan oleh Buang Abdullah, Sularjo, Heni Safitri, Cahyono, dan Bambang Kustianto. Varietas ini dilepas pada tahun 2012 berdasarkan SK Menteri Pertanian 2417/Kpts/SR.120/7/2012 dengan karakteristik umur tanaman \pm 113 hari. Rata-rata hasil 6,9 ton/ha GKG dengan potensi hasil sebesar 9,2 ton/ha GKG. Bentuk tanaman tegak dengan tinggi $\pm 112 \mathrm{~cm}$. Gabah berwarna kuning berbentuk gemuk/lonjong. Tekstur nasi pulen wangi pandan (aromatik). Ketahanan terhadap hama dan penyakit yaitu tahan terhadap wereng batang coklat biotipe 1 , agak tahan biotipe 2 dan 3. Tahan terhadap penyakit hawar daun bakteri patotipe III, agak tahan patotipe IV, dan rentan patotipe VIII.Baik ditanam di sawah dataran rendah sampai sedang (0600) mdpl(Badan Penelitian dan Pengembangan Pertanian, 2016).

b. Varietas Inpari 4

Varietas Inpari 4 ditemukan oleh 2 pemulia yaitu Aan Andang Darajat dan Bambang Suprihatno, varietas ini dilepas pada tahun 2008berdasarkan SK Menteri Pertanian No 954/Kpts/SR.120/7/2008 dengan karakteristik umur tanaman 115 hari. Rata-rata hasil 6,04ton/ha dengan potensi hasil sebesar8,80 ton/ha. Bentuk tanaman tegak dengan tinggi 95-105 $\mathrm{cm}$. Gabah berwarna kuning bersih berbentuk panjang ramping dengan tekstur nasi pulen. Ketahanan terhadap hama dan penyakit yaitu agak rentan terhadap hama Wereng Batang Coklat Biotipe 1,2, dan 3. Agak tahan terhadap penyakit Hawar Daun Bakteri strain III dan IV serta virus tungro inokulum variasi 013 dan rentan terhadap penyakit Hawar Daun Bakteri strain VIII. (Badan Penelitian dan Pengembangan Pertanian, 2016).

c. Varietas Ciliwung

Varietaspadi sawah ini memiliki umur tanam 117-125 hari.Bentuk tanaman tegak dengan tinggi tanaman 114-124 cm. Jumlah anakan produktif yakni 18-25 batang. Gabah berwarna kuning bersih berbentuk sedang sampai ramping. Ciliwung memiliki tekstur nasi pulen. Rata-rata hasil mencapai 4,8 ton/ha dengan potensi hasil sebesar 6,5 ton/ha. Tahan terhadap hama wereng coklat biotipe 1, 2 dan rentan wereng coklat biotipe 3. Ketahanan terhadap penyakit yakni agak tahan terhadap 
hawar daun bakteri strain IV. Varietas ini cukup baik ditanamdi lahan irigasi dengan ketinggian rendah sampai 550 mdpl(Badan Penelitian dan Pengembangan Pertanian, 2016).

\section{Hama/Penyakit Tanaman Padi}

Padi (Oryza sativa) merupakan makanan pokok bagi sebagian besar penduduk Indonesia. Permintaan akan komoditas ini dari tahun ke tahun mengalami lonjakan sejalan dengan bertambahnya jumlah penduduk dengan laju pertumbuhan penduduk rata-rata $1,34 \%$ per tahun. Segregasi yang terjadi pada tanaman padi yang dapat terlihat secara visual adalah segregasi fenotipe yang meliputi antara lain tinggi tanaman dan jumlah anakan. Segregasi fenotipe dapat terlihat apabila tanaman padi yang ditanam di lahan budidaya memiliki tinggi yang tidak seragam dan jumlah anakan yang berbeda untuk tiap-tiap rumpun padi (Badan Ketahanan Pangan dan PenyuluhanPertanian Aceh, 2009).

Menurut Badan Ketahanan Pangan dan Penyuluhan Pertanian Aceh (2009), hama dan penyakit pada tanaman padi sangat beragam, di samping faktor lingkungan (curah hujan, suhu, dan musim) yang sangat berpengaruh terhadap produksi padi. Terdapat beberapa jenis hama pada tanaman padi yaitu:

\section{Ulat penggerek (Scahnobius Bipunctifer)}

Penggerek batang termasuk hama paling penting pada tanaman padi yang sering menimbulkan kerusakan berat dan kehilangan hasil yang tinggi. Di lapangan, kehadiran hama ini di tandai dengan adanya ngengat (kupukupu), kematian tunas padi, kematian malai dan adanya ulat (larva) penggerek batang. Ulat ini dapat merusak tanaman pada semua fase pertumbuhan, baik pada saat pembibitan, fase anakan, maupun fase berbunga. Bila serangan terjadi pada fase pembibitan sampai fase anakan, hama tersebut biasanya disebut sundep dan jika terjadi pada saat tanaman berbunga maka disebut beluk. Gangguan dan kerusakan pada tanaman padi, terutama pada daerah pegunungan biasanya daya perusaktertuju pada bagian-bagian pucuk tanaman sehingga mematikantanaman padi (Siregar, 2007).

Sampai saat ini belum ada verietas tanaman padi yang tahan terhadap serangan hama penggerek batang. Oleh karena itu gejala serangan hama ini perlu diwaspadai, terutama pada pertanaman musim hujan. Waktu tanam yang tepat, merupakan cara yang efektif untuk menghindari serangan penggerek batang. Pada bulan Desember-Januari suhu kelembaban tinggi dan curah hujan pada saat itu sangat cocok bagi perkembangan hama penggerek batang, sementara tanaman padi yang baru saja ditanam sangat sensitif terhadap serangan hama ini. Tindakan pengendalian harus segera dilakukan, apabila $\geq 10 \%$ rumpun memperlihatkan gejala sundep atau beluk. Untuk penanganan hama penggerek batang dapat dilakukan pemberian intektisida.

\section{Hama Putih Palsu (Leaffolder)}

Hama putih palsu jarang menjadi hama utama untuk tanaman padi. Serangan menjadi berarti bila kerusakan daun pada anakan maksimum dan fase pematangan mencapai $\geq 50 \%$. Kerusakan akibat serangan hama putih palsu dapat terlihat ketika adanya warna putih pada pemukaan daun tanaman padi. Larva memakan jaringan hijau daun dari dalam lipatan daun dan meninggalkan permukaan bawah daun yang berwarna putih.

Tanda pertama adanya serangan hama putih palsu adalah kehadiran ngengat yang berwarna kuning kecoklatan yang memiliki 3 buah pita hitam dengan garis lengkap atau terputus pada bagian sayap depan. Untuk pengendalian hama putih palsu 
dapat dilakukan pengupayaan pemeliharaan tanaman dengan sebaik mungkin agar tanaman dapat tumbuh baik,sehat, dan seragam, menggunakan intekstisida (bila diperlukan), jangan menggunakan inteksida sampai tanaman berumur 30 hari setelah tanaman pindah atau 40 hari setelah sebar benih, serta tanaman padi yang terserang pada fase ini dapat pulih apabila air dan pupuk di kelolah dengan baik.

3. Tikus (Rat)

Tikus merusak tanaman padi pada semuafase tumbuh dari semai hingga panen, bahkan sampai pada penyimpanan.Tikus menyerang padi pada malam hari dan pada siang hari, tikus bersembunyi dalam sarangnyadi tanggul-tanggul irigasi, jalan sawah, pematang, dan daerah perkampungan dekat sawah (Syam dkk, 2011).

4. Blas (Blast)

Penyakit blas dikenal sebagai salah satu kendala utama pada padi gogo.Penyakit yang mampu menurunkan hasil sangat besar ini disebabkan oleh jamur pathogen pyricularia grisae.Penyakit blas menimbulkan dua gejala khas yaitu blas daun dan blas leher.Blas daun merupakan bercak coklat kehitaman, berbentuk belah ketupat dengan pusat bercak berwarna putih.Sedangkan blas leher berupa bercak coklat kehitaman pada pangkal leher dapat mengakibatkan leher malai tidak mampu menopang malai dan patah (Syam dkk, 2011).

Hama dan penyakit pada tanaman padi dapat menurunkan kualitas produk pertanian sehingga menyebabkanbanyak kerugian ekonomi. Cara mendeteksi gejala serangan hama dan penyakit sangat penting untuk diketahui dalam bidang pertanian. Cara mengetahui adanya serangan hama dan penyakit pada tanaman padi sedang dilakukan dengan pendekatan visual, yaitu mengandalkan tenaga manusia untuk mendeteksi serangan hamadan penakit pada tanaman. Namun mendeteksi serangan hama dan penyakit pada tanaman secara visual memakan waktu lama. Oleh karena itu dibutuhkan suatu teknologi yang dapat digunakan untuk mendeteksi serangan hama dan penyakit pada tanaman. Pengindraan jauh digunakan dibidang pertanian selama beberapaa dekade. Salah satu penggunaan pengindraan jauh yaitu penilaian penyakit tanaman. Data reflektansi ditemukan mampu mendeteksi perubahaan sifat biofisik daun tanaman dan kanopi yang terkait dengan patogen dan hama serangga (Apan et. al, 2005).

\section{Reflektansi Gelombang Elektromagnetik Tanaman}

Secara pengukuran tradisional dari parameter tanaman sebagai contoh luas permukaan daun dan biomassa biasanya membosankan dan mahal.Denganmenggunakan teknik-teknik baru, pengumpulan data tanaman dan parameter tanah memiliki banyak keunggulan dibandingkan pengukuran tanah dengan menggunakan teknik lama dan telah diketahui.Dengan demikian, telah banyak penelitian yang dilakukan untuk menentukan parameter tanaman oleh penginderaan jauh memanfaatkan fitur spektral reflektansi daun.Semua peristiwa tentang energi cahaya dipermukaan apapun dicerminkan, diserap atau dikirimkan.Reflektansi adalah rasio jumlah cahaya yang dipantulkan dari pesawat untuk radiasi ke pesawat tersebut, menentukan bahwa reflektansi cahaya pada daun dan transmisi berdasarkan refleksi kritis dari cahaya tampak pada dinding sel udara antar muka pada jaringan mesofil spons(Tanriverdi et al. 2006). 

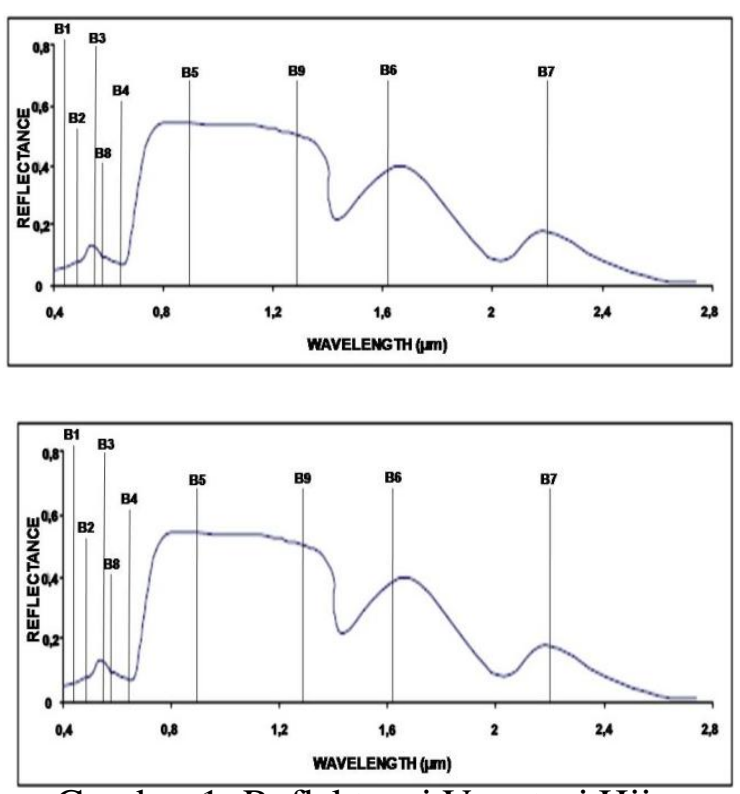

Gambar 1 :Reflektansi Vegetasi Hijau (Tanriverdi et al, 2006)

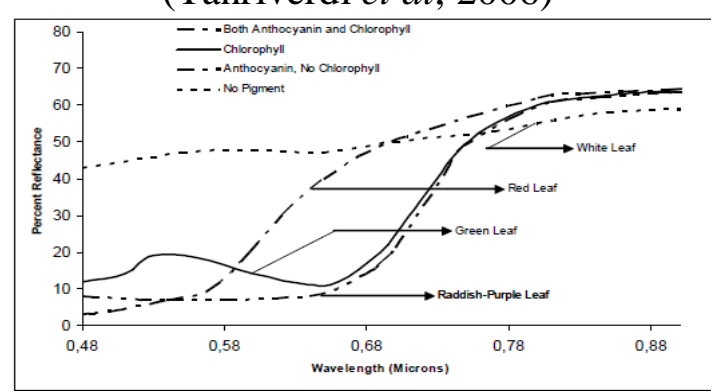

Gambar 2 :Reflektansi yang dihasilkan oleh pigmendaun yang berbeda (Tanriverdi et al, 2006)

Untuk memudahkan interpretasi, yang $0,5-2,5 \mathrm{pm}$ spektrum panjang gelombang dipisahkan menjadi tiga bagianberikut ini:

1. Panjang gelombang spektrum antara 0,5-0,75 pm daerah penyerapan cahaya tampak didominasi oleh pigmen klorofil a dan b, karoten, dan pigmen xantofil;

2. Panjang gelombang spektrum antara 0,75 sampai $1,35 \mathrm{pm}$ daerah inframerah-dekat yang dipengaruhi oleh struktur daun internal; dan

3. Panjang gelombang spektrum antara 1,35-2,5 pm, suatu daerah berpengaruh terhadap beberapa jumlah oleh struktur daun, Namun secara signifikan dipengaruhi oleh konsentrasi air dalam jaringan (Tanriverdi et al. 2006).
Perubahan isi klorofil daun, dapat ditentukan dengan menggunakan pengukuran reflektansi. Beberapa perbedaan ditandai dalam spektrum tanggapan karena pigmen daun yang berbeda.Thomas and Oerther (1972) mengilustrasikan bahwa isi klorofil tergantung pada tingkatan nitrogen dalam vegetasi, faktanya, tingkatan nitrogen memiliki hubungan dengan puncak 0.55 $\mu \mathrm{m}$.Vegetasi Indeks untuk memantau terestrial lanskap melalui sensor itu untuk pertama kalinya dikembangkan di tahun 1970-an dan telah terbukti sangat sukses dalam menilai kondisi vegetasi, dedaunan, dan proses seperti evapotranspirasi dan produktivitas. Meskipun berbagai vegetasi indeks telah dirumuskan, kebanyakan berkaitan dengan rasio yang sederhana (Tanriverdi et al. 2006):

$S R=N I R / R E D$

Keterangan:

SR : Simple Ratio

NIR : Near Infra Red

Salah satu metode yang paling efektif untuk mengukur perubahan tutupan vegetasi adalah dengan perbedaan Normalized Vegetasi Index (NDVI) klasifikasi.NDVI adalah model yang menggunakan informasi diferensial yang timbul dari sifat-sifat reflektansi spektral khas vegetasi sehat dalam merah (red) dan dekat infra-merah (NIR) bagian dari elektromagnetik spektrum.Salah satu keuntungan utama dari NDVI adalah kecenderungannya untuk menghilangkan kesalahan yang dapat mempengaruhi sifatsifat spektral vegetasi.Hal ini karena permukaan vegetasi hijau menyerap cahaya secara proporsional lebih merah dan cahaya inframerah kurang dari permukaan lainnya (Naibibi et al. 2014).

Indeks vegetasi berupa besaran nilai kehijauan vegetasi yang diperoleh dari pengolahan sinyal dijital data nilai kecerahan (brightness) beberapa kanal data sensor satelit. Untuk pemantauan vegetasi, dilakukan proses perbandingan 
antaratingkat kecerahan kanal cahaya merah (red) dan kanal cahaya inframerah dekat (near infrared). Nilai perbandingan kecerahan kanal cahaya merah dengan cahaya inframerah dekat atau NIR/RED, adalah nilai suatu indeks vegetasi (yang sering disebut "simple ratio" yang sudah tidak dipakai lagi. Hal ini disebabkan karena nilai dari rasio NIR/RED akan memberikan nilai yang sangat besar untuk tumbuhan yang sehat. Oleh karena itu, dikembangkanlahalgoritmasuatu indeks vegetasi yang baru dengan normalisasi, yaitu Normalized Difference Vegetation Index (NDVI) seperti berikut ini (Sudiana dan Elfa, 2008):

$N D V I=\frac{\left[\left(\frac{N I R}{R E D}\right)-1\right]}{\left[\left(\frac{N I R}{R E D}\right)+1\right]}$

Yang ekivalen dengan

$N D V I=\frac{N I R-R E D}{N I R+R E D}$.

Keterangan :

NIR : Near Infra Red

\section{NDVI : Normalized Vegetasi Index}

Indeks vegetasi berbasis NDVI yang ditunjukkan pada persamaan (3), mempunyai nilai yang hanya berkisar antara -1 (non-vegetasi) hingga 1 (vegetasi). Dimana NIR dan Red adalah nilai-nilai pemantulan Merah dan Near Infra Red cahaya yang diterima disensor. Hal ini menghasilkan kontras penyerapan yang kuat diband panjang gelombang sempit $650-850$ nm, ditangkap oleh NDVI. NDVI menormalkan nilai antara - 1 sampai +1 , vegetasi padat memiliki NDVI tinggi, sementara nilai tanah yang rendah tetapi positif, dan air negative karena penyerapan yang kuat dari NIR (Sinadia, 2015).

Terdapat hubungan antara tingkat kehijauan tanaman (greenness) dengan produktivitas tanaman padi sawah (didapat dari ubinan/crop cuttingexperiment).Fase pertumbuhan tanaman yang diduga mempunyai hubungan erat dengan produktivitas tanaman padi adalah tanaman pada fase awal generatif (pinnacle initiation) yaitu pada saat tanaman padi sedang produksi (Wahyunto, 2006).

\section{Sistem Penginderaan Jauh}

Penginderaan jauh dapat didefinisikan sebagai metode untuk memperoleh informasi spasial mengenai objek yang dilakukan dari jarak jauh atau tidak langsung bersentuhan dengan objek yang diamati. Dalam penggunaannya penginderaan jauh dapat diklasifikasikan menjadi dua yaitu penggunaan secara langsung dan penggunaan secara tidak langsung. Penggunaan secara langsung yaitu gambar yang digunakan untuk memperoleh informasi tentang tanahdan dijalankan oleh komputer (Tanriverdi et al. 2006).

Penginderaan jauh dapat digunakan sebagai alat deteksi dan pemantauan jika area tanaman yang rusak oleh penyakit seperti infeksi dan infestasi serangga yang cukup besar. (Das et al. 2013).

\section{Spektrometer}

Spektrometer merupakan instrumen yang digunakan untuk menghasilkan spektrum panjang gelombang cahaya, baik spektrum absorpsi, spektrum transmisi, spektrum reflektansi dan spektrum emisi dari sebuah obyek. Secara umum spektrometer terdiri dari sumber cahaya, pemilih panjang gelombang (wavelength selector) dan detektor.Sumber radiasi dapat berupa lampu incandescent dan lampu tungsten halogen.Lampu incandescent dapat menghasilkan spektra yang kontinyu dari panjang gelombang $350 \mathrm{~nm}$ hingga daerah NIR $2.5 \mu \mathrm{m}$.Lampu incandescent memiliki kawat filamen berupa tungsten yang dipanaskan oleh arus listrik.Filamen dibungkus oleh tabung gelas yang berisi gas inert atau vakum.Sedangkan lampu tungsten halogen merupakan lampu incandescent dengan penambahan iodin.Spektrometer juga merupakan salah satu alat yang dapat digunakan untuk mengukur atau menganalisis suatu panjang gelombang cahaya dengan menggunakan difraksi atau prisma untuk memisahkan panjang 
gelombang cahaya yang berbeda (Yulianto dan Agus, 2012).

Spektrometer mempunyai kemampuan untuk panjang gelombang tertentu sesuai dengan tipe alat. Secara umum yang dapat diukur oleh spektrometer adalah intensity (intensitas), absorbance (serapan), transmission (transmisi), reflektion (pantulan), dan relative irradiance. Dalam proses perekaman spektral daun padi hanya digunakan kemampuan proses reflection. Sesuai dengan tipe spektrometer, yaitu tipe florenscence maka sensor yang digunakan memiliki kemampuan rekam panjang gelombang dalam rentang efektif 200 sampai 1.100 nanometer. Perekaman spektral daun tanaman padi memerlukan sumber energi sebagai sumber dari gelombang yang akan dipantulkan oleh obyek. Sehubungan dengan pengukuran yang akan dilakukan adalah pengukuran di luar ruangan, maka sumber energi akan menggunakan sinar matahari (Sanjaya, 2012).

Sinar matahari sebagai sumber cahaya mempunyai beberapa hal yang dapat menguntungkan dan sekaligus merugikan dalam proses pengukuran. Tentunya akan menimbulkan juga pengaruh pada hasil akhir dari pengukuran. Sehingga dalam proses perekaman dilakukan beberapa antisipasi terkait kondisi situasional. Perekaman dengan menggunakan cahaya matahari konsekuensinya sangat tergantung pada kondisi cuaca lokal pada saat melakukan pengukuran. Kondisi terbaik sudut datang sinar matahari pada saat waktu lokal menunjukkan jam 10.00 hingga jam 14.00 (Sanjaya, 2012).

Instrumen yang digunakan untuk menangkap objek hiperspektral dikenal dengan spectrometer imaging. Pengembangan instumen ini, melibatkan dua teknologi yang berbeda, yang terkait satu dengan yang lainnya.Spektroskopi (spectroscopy) dan remote imaging (penginderaan) objek dipermukaan bumi. Spektroskopi adalah studi tentang cahaya yangdipancarkan atau dipantulkan oleh material atau kombinasi (campuran) antar material, yang terkait dengan panjang gelombang sebagai perwakilan dari energi yang diterima/dipentulkan oleh objek (Darmawan, 2012).

Instrumen dari spektroskopi ini dikenal dengan nama spektrometer (spectrometer) atau spektroradiometer (spectroradiometer), yang digunakan untuk mendapatkan informasi tentang spektrum cahaya yang dipantulkan oleh material uji yang dilakukakn dilaboraturium. Elemen dispersi optis (seperti prisma) yang ada pada spektrometer membagi cahaya dalam kanal-kanal sempit, kemudian panjang gelombang yang berdekatan dan energi dari setiap kanal direkam oleh detektordetektor.Dengan menggunakan ratusan atau bahkan ribuan detektor, spektrometer dapat mengukur spektral dari kanal yang panjang gelombangnya berkisar 0.4-2.4 mm (panjang gelombang dari cahaya tampak sampai infra merah tengah) (Darmawan, 2012).

Nilai reflektansi spektral (Spectral Reflectance, selanjutnya disebut spektra) merupakan perbandingan antara energi yang dipantulkan dengan energi yang sampai pada suatu objek sebagai fungsi panjang gelombang.Spektra merupakan suatu kwantitas tanpa unit yang mencakup harga dari 0 sampai 1.0, atau dapat juga dinyatakan sebagai persentase. Spektra ini penting, sebagai alat bantu dalam interpretasi citra hiperspektral. Nilai spektra bervariasi terhadap panjang gelombang untuk hampir semua material sebab energi pada panjang gelombang tertentu dihamburkan atau diserap ke tingkat derajat yangberbeda. Variasi spektra akan tampak jelas ketika kita membandingkan kurva spektra dengan kurva panjang gelombang untuk material yang berbeda, seperti yang ditampilkan pada Gambar 3 (Suhaimi, 2015). 


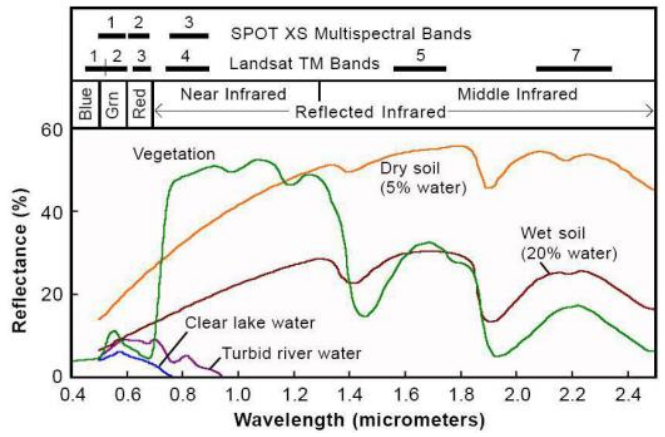

Gambar 3. Kurva Spektra Terhadap Panjang Gelombang $(0.4-2.5 \mu \mathrm{m})$

Bentuk suatu kurva spektra serta posisi dan kekuatan daya serap kanal dapat digunakan untuk mengidentifikasi dan memilah material yang berbeda.Sebagai contoh, tumbuh-tumbuhan mempunyai spektra (daya pantul) lebih tinggi pada kanalinframerah-dekat dan memiliki spektral lebih rendah daripada tanah (soil) pada band merah.Spektra dari tumbuhan hijau yang sehat mempunyai bentuk yang khusus.Bentuk kurva dipengaruhi oleh absorbsi dari pigmen hijau (klorofil) dan pigmen daun lainnya. Klorofil menyerap cahaya tampak dengan sangat efektif tetapi menyerap panjang gelombang merah dan biru lebih kuat dibanding hijau, sehingga tumbuhan yang sehat akan berwarna hijau. Lihat Gambar 4. (Suhaimi, 2015).

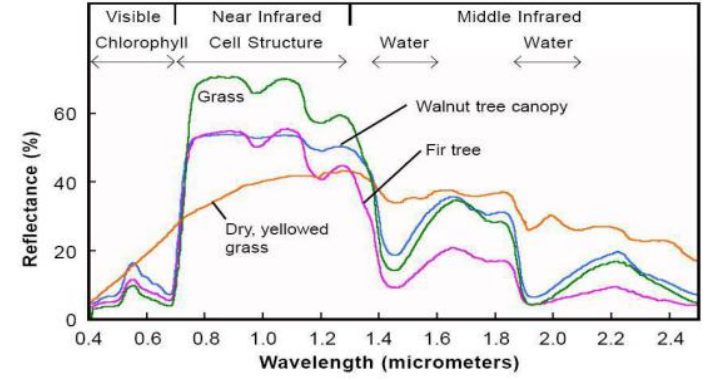

Gambar 4. Kurva Spektra Beberapa Jenis Tumbuhan

\section{SpectralWiz®}

Spectrawiz@, StellarNet-Laser 2000 merupakan program perangkat lunak utama untuk setiap spektrometer, telah banyak dibangun dalam aplikasi untukSpectro Radiometry, Spektrofotometri Colorimeter, Spectro Chemistry, Optical Analisis spektral, Kalibrasi, dan banyak lagi. Spektrawiz ${ }^{\circledR}$ memungkinkan pengguna untuk mengubah berbagai parameter yang mengendalikan operasi spektrometer dan bagaimana data ditampilkan secara realtime.Sebagai contoh, tampilan spektral dapat diperbesar, snap shot, dicetak, digambarkan, diekspor, overlayed dan digambarkan dalam 3D (Suhaimi, 2015).

\section{METODE PENELITIAN}

\section{Waktu dan Tempat}

Penelitian analisis serangan hama pada tanaman padi menggunakan spektrometer dilaksanakan pada bulan Mei hingga Agustus 2016 bertempat di Wilayah Desa Alatengae, Kecamatan Bantimurung, Kabupaten Maros.

\section{Alat dan bahan}

Alat yang digunakan pada penelitian ini yaitu meteran, spectrometer stellarnet green wave dengan panjang gelombang 400-1100 nm, laptop, stellarnet software 5.3, dan luxmeter. Bahan yang digunakan pada penelitian ini yaitu peta dasar lahan petakan sawah, alat tulis, patok dan tali rapiah.

\section{Prosedur Penelitian}

Penelitian analisis serangan hama pada tanaman padi menggunakan spektrometer ini dilakukan dengan langkahlangkah sebagai berikut:

\section{Melakukan survey lapangan}

Survey lapangan dilakukan untuk menentukan lokasi yang akan di jadikan tempat penelitian.

\section{Menentukan lokasi pengamatan}

Pengamatan lokasi dilakukan untuk menentukan petakan sawah yang sedang di analisis jenis dan tingkat serangan hama pada lahan sawah. Petak sawah dipilih sesuai dengan tingkat dan jenis serangan hama atau penyakit yang terdapat pada tanaman padi.

Melakukan pengelompokkan jenis dan tingkat serangan hama pada tanaman padi 
Pengelompokkan jenis dan serangan hama pada tanaman padi yang terdapat pada petak lahan sawah yang telah ditentukan sebelumnya. Penentuan pengelompokkan ini dilakukan sesuai dengan tingkat dan jenis serangan hama atau penyakit yang terdapat pada tanaman padi.

\section{Melakukan pengambilan data dengan spektrometer}

Pengambilan data penggunakan spektrometer seusai dengan jenis dan tingkat serangan hama pada tanaman padi yang dilakukan sebanyak \pm 5 kali pengambilan data, pada saat terdeteksi adanya serangan hama, tanaman padi memasuki fase primodia (bunting), fase berbunga, fase pematangan dan pada saat tanaman siap panen.

\section{Mengambil data tanaman yang terserang hama (foto vertikal/horisontal)}

Pengambilan data tanaman yang terserang hama (foto vertikal/horisontal) dilakukan untuk mengumpulkan data dan sebagai tambahan data tanaman padi yang terserang hama/penyakit.

\section{Melakukan pengolahan data dengan software spektrawiz}

Pengolahan data jenis dan tingkat serang hama yang terdapat pada tanaman padi sehingga menghasilkan keluaran berupa grafik.

\section{Menentukan panjang gelombangspesifik untuk serangan hama/penyakit}

Menentukan panjang gelombang spesifik bertujuan untuk mengklasifikasikan jumlah serangan hama yang terdapat pada tanaman padi sesuai dengan panjang gelombangnya.

\section{Menghitung indeks vegetasi untuk serangan hama.}

Melakukan perhitungan indeks vegetasi serangan hama dari data yang telah diambil menggunakan spektrometer menggunakan rumus indeks vegetasi pada persamaan (3).

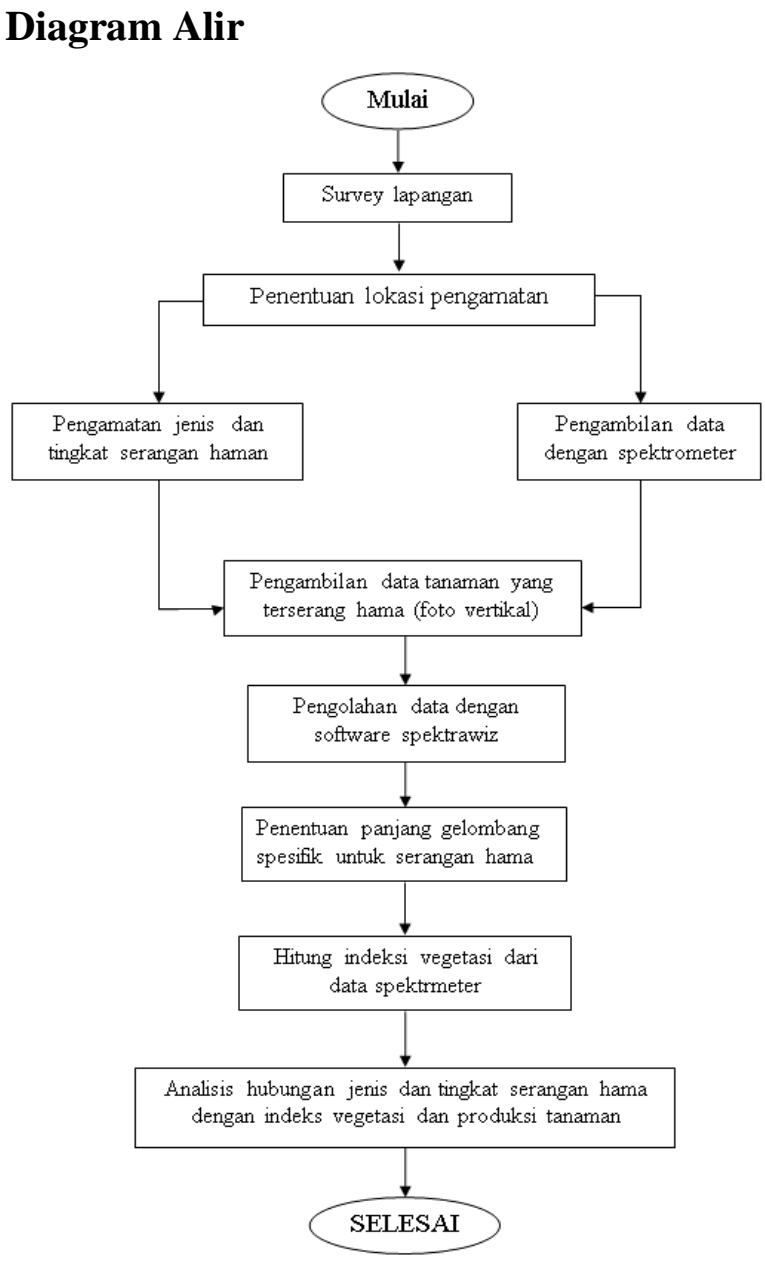

\section{HASIL DAN PEMBAHASAN}

\section{Reflektansi Tanaman Padi}

Pada penelitian ini dilakukan pengamatan serangan hama putih dan hama penggerek batang berdasarkan hasil reflektansi tanaman padi yang didapatkan dilapangan.

Terdapat tiga jenis varietas tanaman padi yaitu varietas Ciliwung, Inpari 4 dan Inpari 23 dengan tingkat serangan hama dari setiap jenis varietas tanaman padi yaitu:

1. Reflektansi tanaman padi varietas Ciliwung

Pengambilan data reflektansi pada petak 67 untuk tanaman padi varietas Ciliwung dilakukan pada tanaman padi sehat dan tanaman padi yang terserang hama. Penelitian ini dilakukan untuk 2 jenis serangan hama yaitu: 
A. Hama Putih

Selama penelitian serangan hama yang muncul adalah serangan hama putih. Serangan hama putih dapat diketahui gejalanya pada saat tanaman padi berumur 42 hari setelah tanam (HST). Serangan hama putih pada tanaman padi dapat dilihat pada Gambar 6.

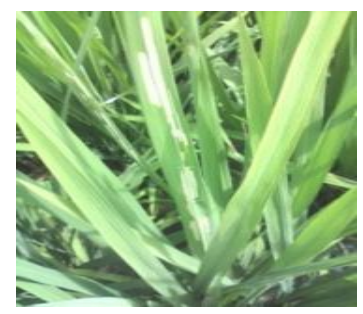

Gambar 6. Tanaman padi terseranghama putih.

Pengambilan data yang dipengaruhi oleh cahaya sehingga diperlukan kehati-hatian dalam pengambilan data mengingat posisi matahari yang selalu berubah dan kondisi cuaca dapat mempengaruhi hasil data yang diperoleh. Reflektansi tanaman padi varietas Ciliwung dapat dilihat pada Gambar 7.

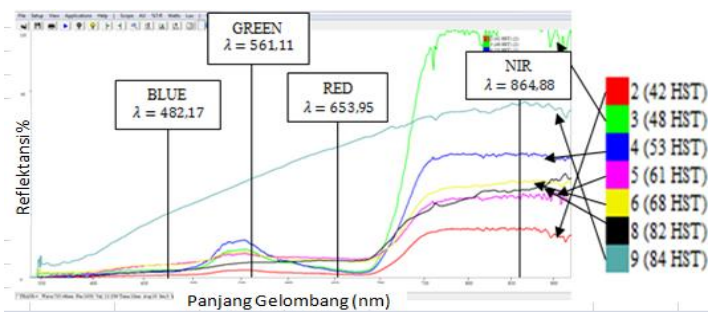

Gambar 7. Reflektansitanaman padi yang terserang hama putih varietas Ciliwung.

Pada Gambar 7 bagian NIR terlihat reflektansi tanaman umur 48 HST lebih tinggi dari reflektansi lainnya dikarenakan pada saat 48 HST tanaman telah berumpun lebat dengan tingkat kehijauan yang tinggi, sedangkan untuk tanaman padi dengan serangan hama tinggi ditunjukkan pada reflektansi hitam dengan nilai NDVI 0,682. Reflektansi biru toska merupakan reflektansi tanaman padi dengan serangan hama yang telah meningkat dari sebelumnya dapat dikatakan serangan hama besar dengan pengambilan data dilakukan pada jarak $\pm 5 \mathrm{~cm}$. Selain pengolahan data menggunakan rumus NDVI dilakukan pula pengolahan data menggunakan rumus NDRE dan RVI yang dapat dilihat hasilnya pada Gambar 8.

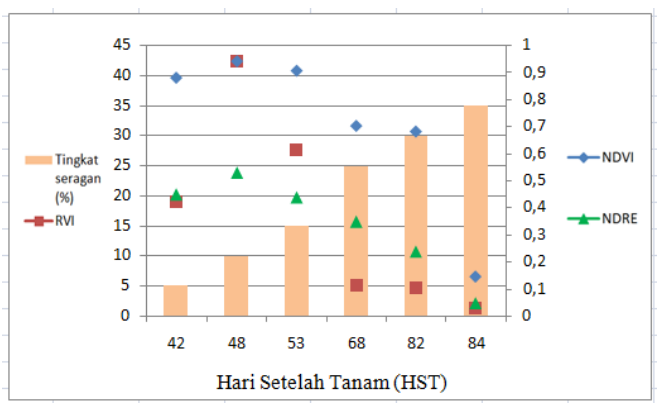

Gambar 8. NDVI, NDRE dan RVI tanaman terserang hama putih varietas Ciliwung.

Berdasarkan hasil pengolahan data reflektansi tanaman padi varietas Ciliwung yang terserang hama putih maka didapatkan nilai NDVI $\mathrm{R}^{2}$ tanaman 0,645 , nilai NDR $\mathrm{R}^{2} 0,896$ dan nilai RVI $\mathrm{R}^{2} 0,653$. Pada 68 hingga 84 HST varietas tanaman padi telah memasuki masa pematangan bulir padi serta adanya serangan hama yang menyebabkan terjadi penurunan nilai. Semakin besar serangan hama yang terdapat pada tanaman maka semakin kecil nilai NDVI, NDRE dan RVI tanaman padi.

B. Hama Penggerek Batang

Adanya serangan hama penggerek batang dapat dideteksi ketika tanaman padi berumur 42 hari setelah tanam (HST) yang ditandai dengan adanya ulat pada pangkal daun tanaman padi muda. Hal ini sesuai dengan pendapat Siregar (2007) yang menyatakan bahwa pada tanaman padi terdapat ulat yang dapat merusak tanaman pada semua fase pertumbuhan, baik pada saat pembibitan, fase anakan, maupun fase berbunga, gejala serangan hama penggerek batang pada tanaman padi dapat dilihat pada Gambar 9. 


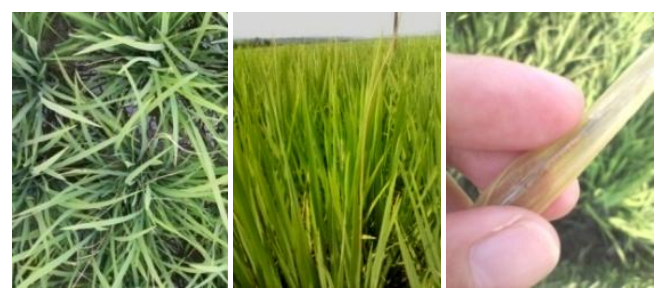

Gambar 9. Hama penggerek batang pada tanaman padi.

Setiap pengambilan data reflektansi tanaman akan didapatkan hasil reflektansi yang berbeda-beda sesuai dengan umur tanaman dan karena adanya serangan hama pada tanaman padi. Reflektansi tanaman padi yang terserang hama penggerek batang varietas Ciliwung dapat dilihat pada Gambar10.

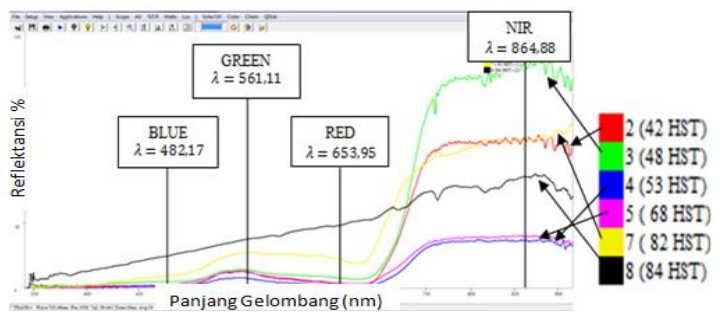

Gambar10. Reflektansitanaman paditerserang hama penggerek batang varietas Ciliwung.

Terdapat perubahan bentuk reflektansi yang dihasilkan, hal ini disebabkan karena terjadinya perubahan warna pada tanaman, perubahan bentuk dan berkurangnya vegetasi tanaman akibat tanaman mati oleh serangan hama. Tanaman dengan tingkat vegetasi tinggi dengan serangan hama masih kurang ditujukkan pada grafik hijau dengan nilai NDVI 0,95 sedangkan untuk tanaman dengan serangan hama besar ditunjukkan pada grafik kuning dengan nilai NDVI 0,68 untuk grafik hitam merupakan hasil panjang gelombang tanaman padi dengan serangan hama yang pengambilan datanya dilakukan $\pm 5 \mathrm{~cm}$ dengan nilai NDVI 0,28. NDVI, RVI dan NDRE reflektansi tanaman padi dapat dilihat pada Gambar 11.

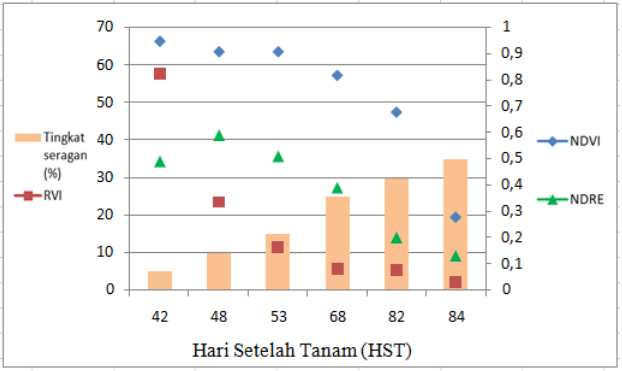

Gambar 11. NDVI, NDRE dan RVI tanaman padi terserang hama penggerek batang varietas Ciliwung.

Nilai NDVI $\mathrm{R}^{2}$ tanaman dengan varietas Ciliwung dari 42 hari setelah tanam (HST) hingga 84 hari setelah tanaman (HST) yaitu 0,645 dan dapat dilihat pada grafik terjadi penurunan, hal ini disebabkan adanya serangan hama penggerek batang yang menyebabkan produksi tanaman berkurang. Untuk nilai NDRE $\mathrm{R}^{2}$ tanaman padi varietas Ciliwung dengan serangan hama penggerek batang memiliki nilai tinggi yaitu 0,984 dan untuk nilai RVI $\mathrm{R}^{2}$ tanaman yaitu 0,716 .

C. Tanaman padi yang sehat

Pengambilan data tanaman padi varietas Ciliwung ini dilakukan sebagai data pembanding untuk varietas yang terserang hama tertentu (penggerek batang dan hama putih) dengan varietas tanaman padi yang sehat. Reflektansi tanaman padi varietas Ciliwung dari data lapangan dapat diliat pada Gambar 12.

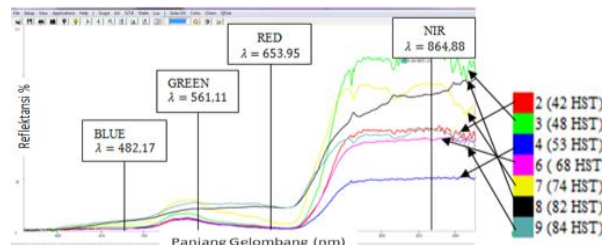

Gambar 12. Reflektansi tanaman padi sehat varietas Ciliwung.

Pada saat varietas padi berumur 48 hari setelah tanam (HST) yang merupakan waktu memasuki fase primodia (bunting) hingga berbunga. Ketika tanaman akan memasuki fase primodia (bunting), pada saat tersebut 
tingkat kehijauan tanaman padi tinggi sehingga reflektansi hijau menunjukkan tingkat vegetasi tanaman sehat. Untuk panjang gelombang hitam dimana tanaman memasuki umur 82 hari setelah tanam (HST) terlihat dari bagian blue, green, red,dan NIR menunjukkan tanaman tidak lagi berwarna hijau, hal ini terjadi karena tanaman telah memasuki masa pematangan dimana ketika padi telah memasuki masa matang daun serta bulir padi akan menguning. Sehingga untuk panjang gelombang hitam dan biru toska menunjukkan tanaman padi telah siap panen. NDVI, RVI dan NDRE dari reflektansi varietas Ciliwung tanaman padi dapat dilihat pada Gambar 13.

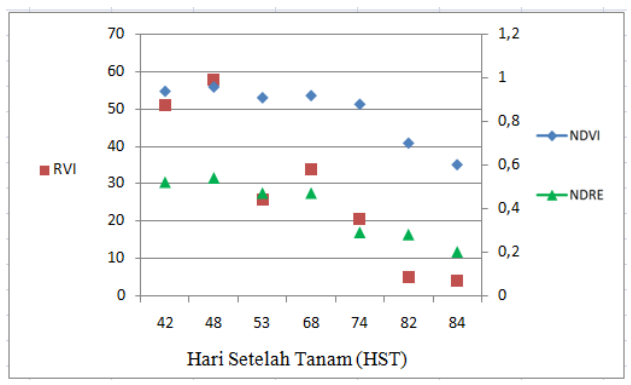

Gambar 13. NDVI, NDRE dan RVI

tanaman padi sehat varietas Ciliwung.

Pada Gambar 13 terlihat nilai NDVI tanaman padi sehat terlihat terjadi penurunan, hal ini karena tanaman padi menguning akibat tanaman telah memasuki fase panen yang menyebabkan tingkat kehijauan tanaman berkurang. NDVI $\mathrm{R}^{2}$ tanaman padi varietas Ciliwung untuk padi yang sehat yaitu 0,917 yang menunjukkan indeks vegetasi tanaman tinggi. Sesuai dengan pendapat Sudiana dan Elfa (2008), indeks vegetasi berupa besaran nilai kehijauan vegetasi yang diperoleh dari pengolahan sinyal dijital data nilai kecerahan (brightness) beberapa kanal data sensor satelit. yang menyatakan bahwa untuk nilai NDRE $\mathrm{R}^{2}$ tanaman yaitu 0,907 dan RVI $\mathrm{R}^{2}$ tanaman yaitu 0,821 .
2. Reflektansi tanaman padi varietas Inpari 4

Pengambilan data pada petak 156 untuk tanaman padi varietas Inpari 4 dilakukan pada tanaman padi sehat dan tanaman padi yang terserang hama. Penelitian ini dilakukan untuk 2 jenis serangan hama yaitu:

A. Hama Putih

Pengambilan data tanaman padi yang terserang hama putih dilakukan pada saat gejala serangan hama putih mulai terlihat yaitu pada saat tanaman padi berumur 42 hari setelah tanaman (HST). Sesuai yang diyatakan oleh Badan Ketahanan Pangan dan Penyuluhan Pertanian Aceh (2009) bahwa kerusakan akibat serangan hama putih palsu dapat terlihat adanya warna putih pada pemukaan daun di tanaman padi. Larva memakan jaringan hijau daun dari dalam lipatan daun dan meninggalkan permukaan bawah daun yang berwarna putih. Reflektansi tanaman dengan serangan hama putih dapat dilihat pada Gambar 17.

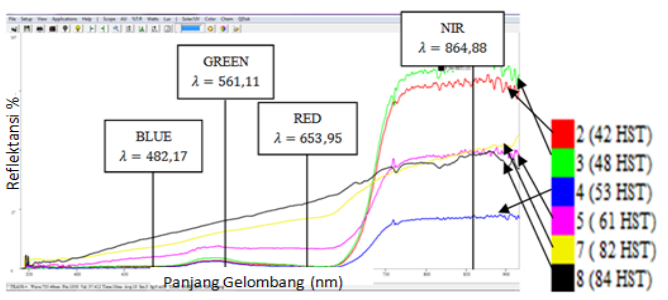

Gambar17. Reflektansi tanaman padi terserang hama putihvarietas Inpari 4.

Pada reflektansi hijau menunjukkan tingkat vegetasi tanaman tinggi dimana tanaman akan memasuki fase primodia (bunting) di umur 48 hari setelah tanam (HST) dengan nilai NDVI 0,974. Terlihat pada Gambar 17 bagian kanal blue green red dan NIR memiliki reflektansi yang naik secara linear selain tanaman menguning karena telah memasuki masa panen, karena adanya serangan hama yang menyebabkan tanaman putih kecoklatan hingga daun tanaman mati. Pada reflektansi kuning dengan umur 82 hari setelah tanaman 
(HST) memiliki nilai NDVI 0,413 yang menunjukkan indeks vegetasi tanaman kurang. Sedangkan untuk reflektansi hitam merupakan reflektansi tanaman terserang hama putih dengan jarak lensa spektrometer ke tanaman $\pm 5 \mathrm{~cm}$ dengan nilai NDVI 0,145. NDVI, NDRE, dan RVI reflektansi tanaman padi terserang hama putih dapat dilihat pada Gambar 18.

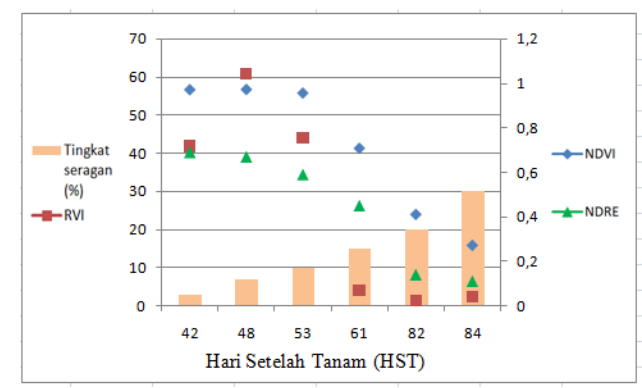

Gambar 18. NDVI, NDRE dan RVI tanaman terserang hama putih varietas Inpari 4.

Untuk tanaman padi Inpari 4 yang terserang hama putih terlihat pada Gambar18 grafik NDVI tanaman semakin menurun yang menunjukkan indeks vegetasi tanaman yang semakin menurun akibat adanya serangan hama yang menyebabkan tanaman padi putih kecoklatan dengan nilai NDVI $\mathrm{R}^{2}$ tanaman yaitu 0,968 . Selain nilai NDVI dilakukan pula pengolahan data NDRE $\mathrm{R}^{2}$ tanaman dan $\mathrm{RVI} \mathrm{R}^{2}$ tanaman. Nilai NDRE $\mathrm{R}^{2}$ tanaman padi terserang hama putih yaitu 0,994 dan untuk nilai RVI $\mathrm{R}^{2}$ tanaman padi yaitu 0,736 .

B. Hama Penggerek Batang

Adanya serangan hama penggerek batang dapat dideteksi pada saat tanaman berumur 42 hari setelah tanam (HST) yang ditandai dengan adanya ulat pada pangkal daun tanaman padi muda. Hal ini sesuai dengan pendapat Siregar (2007) yang menyatakan bahwa pada tanaman padi terdapat ulat yang dapat merusak tanaman pada semua fase pertumbuhan, baik pada saat pembibitan, fase anakan, maupun fase berbunga. Bila serangan terjadi pada fase pembibitan sampai fase anakan, hama tersebut biasanya di sebut sundep dan jika terjadi pada saat tanaman berbunga maka di sebut beluk. Reflektansi tanaman padi terserang hama penggerek batang dapat dilihat pada Gambar 19.

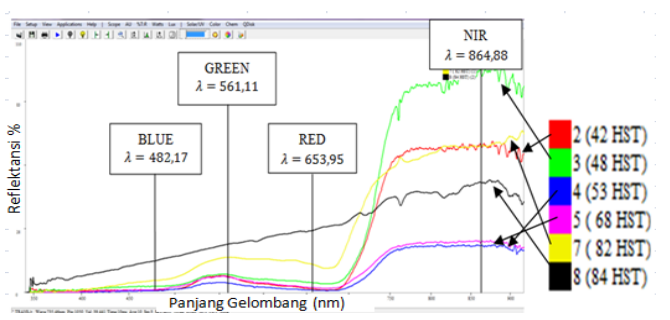

Gambar19. Reflektansi tanaman padi terserang hama penggerek batang varietas Inpari 4.

Pada Gambar 19 terlihat terdapat beberapa panjang gelombang tanaman padi yang terserang hama penggerek batang. Tanaman dengan serangan hama penggerek batang masihh sangat sedikit di tunjukkan pada panjang gelombang merah. Panjang gelombang merah dapat menunjukkan serangan hama pada tanama masihh kurang dan tanaman telah memasuki fase primodia (bunting) dengan nilai NDVI 0,969. Sedangkan pada panjang gelombang kuning menunjukkan serangan hama penggerek batang pada tanaman padi dapat dikatakan serangan hama berat dengan nilai NDVI 0,413. Untuk panjang gelombang hitam merupakan panjang gelombang tanaman padi dengan serangan hama penggerek batang dengan pengambilan data jarak lensa spektrometer $\pm 5 \mathrm{~cm}$. Pada panjang gelombang kuning dan hitam terlihat hampir memiliki panjang gelombang yang sama meski dilakukan pengambilan data dengan jarak yang berbeda, hal ini menunjukkan pada tanaman padi varietas Inpari 4 petak 156 dengan serangan hama penggerek batang merupakan serangan hama berat dibandingkan dengan serangan hama penggerek batang pada petak 67 varietas Ciliwung dan petak 271 varietas Inpari 23. NDVI, NDRE, dan RVI dari 
reflektansi tanman padi terserang hama penggerek batang dapat dilihat pada Gambar 20.

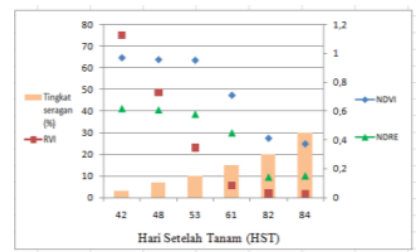

Gambar 20. NDVI, NDRE, dan RVI tanaman padi varietas Inpari4 yang terserang hama penggerek batang varietas Inpari 4.

Tanaman padi varietas Inpari 4 dengan serangan hama penggerek batang setelah melakukan pengambilan data menggunakan alat spektrometer kemudian dilakukan pengolahan data. Dari pengolahan data panjang gelombang tanaman yang terserang hama kemudian didapatkan nilai NDVI $\mathrm{R}^{2}$ tanaman padi yang terserang hama penggerek batang yaitu 0,955. Selain nilai NDVI $\mathrm{R}^{2}$ tanaman padi didapatkan pula nilai NDRE $\mathrm{R}^{2}$ tanaman padi yaitu 0,989 dan RVI $\mathrm{R}^{2}$ tanaman padi 0,994. Semakin besar serangan hama peda tanaman padi maka semakin renda NDVI, NDRE dan RVI . Pada umur 84 HST nilai NDVI $=0,375, \mathrm{RVI}=1,830$ dan NDRE $=0,150$ dengan tingkat serangan hama $30 \%$.

C. Tanaman Sehat

Pengambilan data tanaman padi dari varietas Inpari 4 ini dilakukan sebagai data pembanding untuk varietas yang terserang hama tertentu (penggerek batang dan hama putih) dengan varietas yang sehat. Reflektansi tanaman padi sehat varietas Inpari 4 dapat dilihat pada Gambar 21.

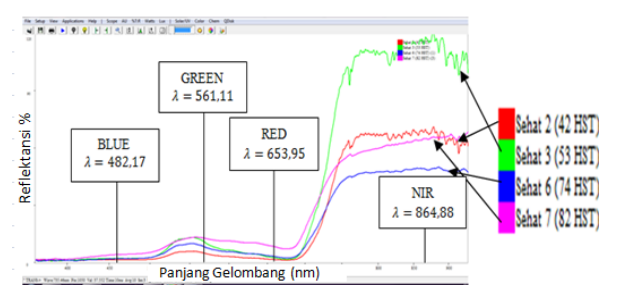

Gambar 21. Reflektansi tanaman padi sehat varietas Inpari 4.

Pada Gambar21dapat terlihat pada panjang gelombang hijau menunjukkan tingkat kehijauan tanaman tinggi dengan nilai NDVI 0,951. Perbedaan tanaman padi yang tidak terserang hama dengan tanaman padi yang terserang hama dapat terlihat pada panjang gelombang tanaman padi umur 82 hari setelah tanaman (HST) tanaman padi. Tanaman padi yang terserang hama pada bagian BLUE GREEN RED dan NIR akan cenderung membentuk garis linear. NDVI, RVI dan NDRE tanaman padi sehat dapat dilihat pada Gambar 22.

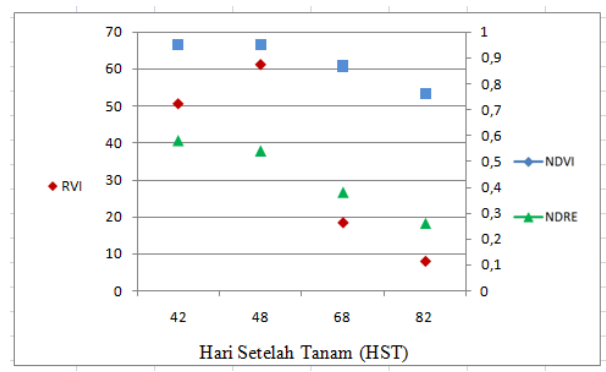

Gambar 22. NDVI, NDRE, dan RVI tanaman padi sehatvarietas Inpari 4.

Pada Gambar 22 untuk nilai NDVI $\mathrm{R}^{2}$ tanaman padi sehat terlihat terjadi penurunan, hal ini karena tanaman padi yang menguning akibat tanaman telah memasuki masa panen. Dari hasil pengolahan data didapatkan nilai NDVI $\mathrm{R}^{2}$ tanaman padi varietas Inpari 4 untuk padi yang sehat yaitu 1 . Selain pengolahan data untuk nilai NDVI $\mathrm{R}^{2}$ tanaman padi, dilakukan pula pengolahan data untuk nilai NDRE $\mathrm{R}^{2}$ tanaman padi yaitu 0,997 dan RVI $\mathrm{R}^{2}$ tanaman padi yaitu 0,89 .

3. Reflektansi tanaman padi varietas Inpari 23

Pengambilan data pada petak 271 untuk tanaman padi varietas Inpari 23 dilakukan pada tanaman padi sehat dan tanaman padi yang terserang hama. Penelitian ini dilakukan untuk 2 jenis serangan hama yaitu: 
A. Hama Putih

Pengambilan data dilapangan mulai dilakukan pada saat serangan hama telah terdeteksi. Serangan hama putih dapat diketahui ketika tanaman berumur 45 hari setelah tanam (HST). Panjang gelombang yang dihasilkan dari pantulan warna tanaman sangat berpengaruh dengan cahaya matahari sehingga pengambilan data di lakukan pada pukul 10.00 sampai 14.00 WITA. Sesuai dengan yang dinyatakan oleh Sanjaya (2012) bahwa sinar matahari sebagai sumber cahaya mempunyai beberapa hal yang dapat menguntungkan dan sekaligus merugikan dalam proses pengukuran. Perekaman dengan menggunakan cahaya matahari konsekuensinya sangat tergantung pada kondisi cuaca lokal pda saat melakukan pengukuran. Kondisi terbaik sudut datang sinar matahari pada saat waktu lokal menunjukkan jam 10.00 hingga jam 14.00. Reflektansi tanaman padi varietas Inpari 23 tersengan serangan hama putih dapat dilihat pada Gambar 26.

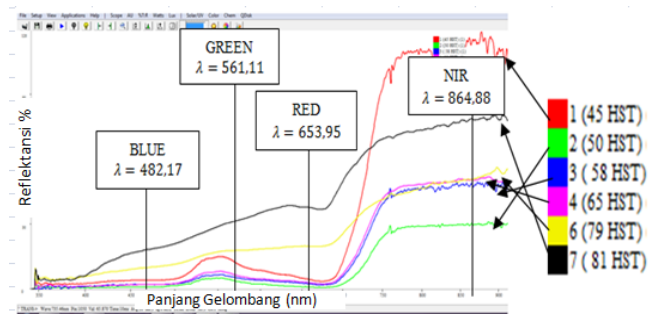

Gambar 26. Reflektansi tanaman padi terserang hama putih varietas Inpari 23.

Tanaman sehat untuk varietas inpari 23 ditunjukkan pada panjang gelombang merah dengan nilai NDVI 0,919, sedangkan untuk tanaman padi dengan serangan hamanya telah besar ditunjukkan pada panjang gelombang kuning dengan nilai NDVI 0,438. Panjang gelombang hitam merupakan panjang gelombang tanaman sakit yang pengambilan datanya dilakukan dengan jarak $\pm 5 \mathrm{~cm}$. NDVI, NDRE dan RVI tanaman padi varietas Inpari 23 dapat dilihat pada Gambar 27.

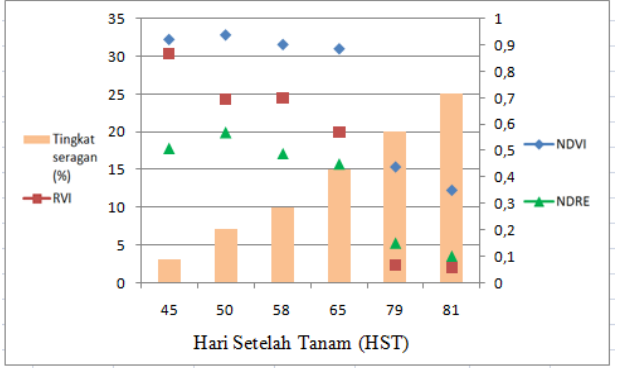

Gambar 27. NDVI, NDRE dan RVI tanaman padi terserang hama putih varietas Inpari 23.

Dari pengolahan data yang dilakukan di dapatkan nilai NDVI $\mathrm{R}^{2}$ tanaman padi yang terserang hama putih yaitu 0,991. Selain nilai NDVI dilakukan pula pengolahan data berdasarkan nilai NDRE $\mathrm{R}^{2}$ tanaman padi dan nilai $\mathrm{RVI} \mathrm{R}^{2}$ tanaman padi. Untuk nilai NDRE $\mathrm{R}^{2}$ tanaman padi varietas inpari 23 dengan serangan hama penggerek batang memiliki nilai tinggi yaitu 0,991 dan untuk nilai RVI $\mathrm{R}^{2}$ tanaman padi yaitu 0,829 .

B. Hama Penggerek Batang

Adanya serangan hama penggerek batang dapat dideteksi pada saat tanaman berumur 45 hari setelah tanam (HST). Pengambilan data dilakukan apabila terlihat adanya perbedaan bentuk atau semakin luasnya serangan hama pada tanaman padi di sekitar tanaman padi yang terserang hama sebelumnya, sehingga diperoleh panjang gelombang yang berbeda setiap kali pengambilan data. Reflektansi tanaman padi varietas Inpari 23 dapat dilihat pada Gambar 28.

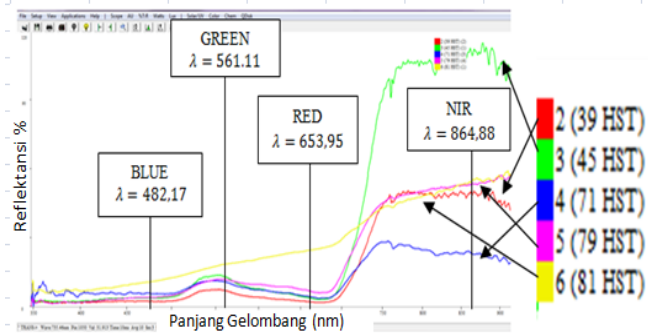

Gambar 28. Reflektansi tanaman padi terserang hama penggerek batang varietas Inpari 23. 
Pada panjang gelombang hijau menunjukka tanaman padi varietas Inpari 23 merupakan tanaman dengan tingkat serangan hama yangmasih sedikit dengan nilai NDVI 0,914 dan pada panjang gelombang pada umur 71 HST merupakan panjang gelombang tanaman yang telah berbunga dan memasuki masa pengisian bulir padi. Untuk panjang gelombang ungu 79 HST menunjukkan tanaman telah menguning sebab telah memasuki masa padi matang dan adanya serangan hama penggerek batang. Untuk panjang gelombang kuning yang menunjukkan adanya serangan hama merupakan pengambilan data yang dilakukan dengan jarak lensa spektrometer dengan tanaman sangat dekat yaitu $\pm 5 \mathrm{~cm}$.Untuk menentukan perbedaan panjang gelombang NDVI, NDRE dan RVI tanaman padi varietas Inpari 23 dapat dilihat pada Gambar 29.

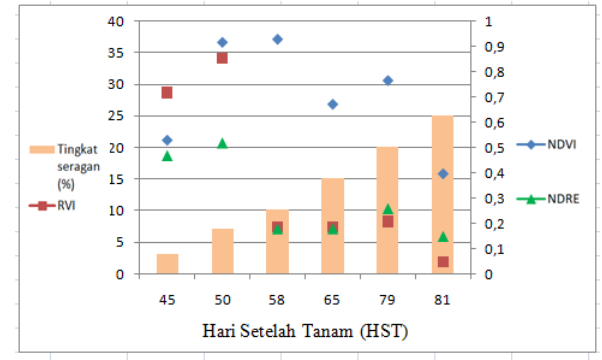

Gambar 29. NDVI, NDRE dan RVI tanaman terserang hama penggerek batang varietas Inpari 23.

Tanaman padi varietas Inpari 23 dengan serangan hama penggerek batang setelah melakukan pengambilan data menggunakan alat spektrometer kemudian dilakukan pengolahan data. Dari pengolahan data panjang gelombang tanaman yang terserang hama kemudian didapatkan nilai NDVI tanaman yang terserang hama penggerek batang yaitu 0,456. Selain nilai NDVI tanaman didapatkan pula nilai NDRE tanaman yaitu 0,991 dan RVI 0,829.

\section{Tanaman Sehat}

Pengambilan data tanaman padi dari varietas inpari 23 ini dilakukan sebagai data pembanding untuk varietas yang terserang hama tertentu (penggerek batang dan hama putih) dengan varietas yang sehat. Reflektansi tanaman padi varietas Inpari 23 sehat dapat dilihat pada Gambar 30.

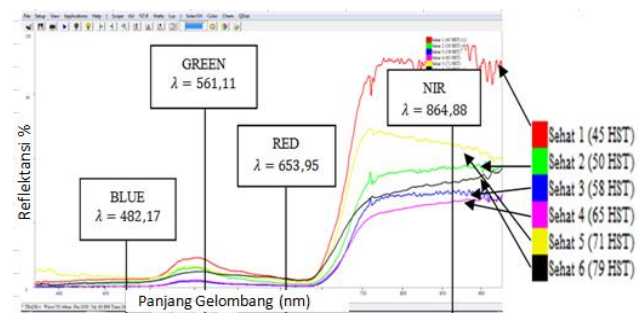

Gambar 30. Reflektansi tanaman padi sehat varietas Inpari 23.

Pada Gambar 30 dapat terlihat pada panjang gelombang merah menunjukkan tingkat kehijauan tanaman tinggi dengan nilai NDVI 0,932. Untuk panjang gelombang hitam menjukkan tanaman padi menguning, hal tersebut karena tanaman telah memasuki masa panen dengan nilai NDVI 0,848. NDVI, NDRE dan RVI tanaman dapat dilihat pada Gambar 31.

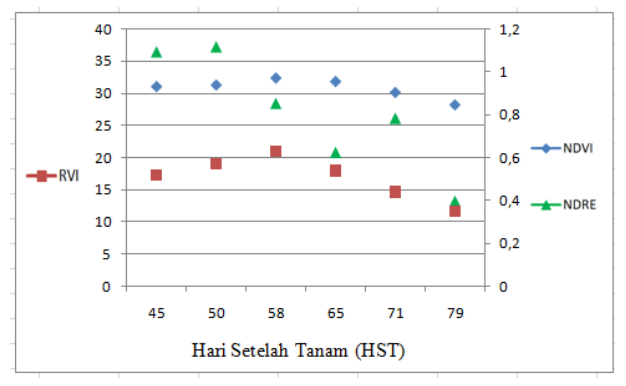

Gambar 31. NDVI, NDRE, dan RVI tanaman padi yang sehat varietas Inpari 23 .

Pada Gambar 31 untuk nilai NDVI Rtanaman padi sehat terlihat terjadi penurunan, hal ini karena tanaman padi yang menguning akibat tanaman telah memasuki masa panen. Setelah melakukan pengambilan data dilapangan menggunakan alat spektrometer kemudian dilakukan pengolahan data. Dari hasil pengolahan data didapatkan nilai NDVI $\mathrm{R}^{2}$ tanaman padi varietas Iinpari 23 untuk padi yang sehat yaitu 0,958. Selain pengolahan data untuk nilai NDVI $\mathrm{R}^{2}$ tanaman padi, dilakukan pula pengolahan data untuk 
nilai NDRE $\mathrm{R}^{2}$ tanaman padi yaitu 0,920 dan $R V I R^{2}$ tanaman padi yaitu 0,863 .

\section{KESIMPULAN}

\section{Kesimpulan}

Berdasarkan hasil penelitian yang telah dilakukan maka dapat disimpulkan:

1. Jenis serangan hama putih dan penggerek batang varietas Ciliwung, Inpari 4 dan Inpari 23 dapat dideteksi dengan baik dengan pengolahan data spektrometer.

2. NDVI, RVI dan NDRE digunakan untuk mendapatkan nilai indeks vegetasi tanaman, dimana NDVI merupakan nilai indeks vegetasi yang memperhitungkan nilai red/NIRsedangkan nilai indeks vegetasi RVI dan NDRE yang memperhitungkan nilai reddari reflektansi yang di hasilkan.

3. Tingkat serangan hama putih dan penggerek batangdapat terdeteksi berdasarkan nilai indeks vegetasi NDVI pada saat terdeteksinya serangan hama umur 42 hari setelah tanam (HST) hingga umur 82 hari setelah tanam (HST).

4. Semakin tinggi tingkat serangan hama (hama putih dan hama penggerek batang) maka semakin rendah nilai indeks vegetasi NDVI, NDRE, dan RVI pada tanaman padi.

\section{DAFTAR PUSTAKA}

Apan, A., Datt, B., and Kelly, R. 2005.

Detection of Pests and Diseases in Vegetable Crops Using Hyperspectral Sensing: A Comparison of Reflectance Data for Different Sets of Symptoms.Melbourne: Spatial Sciences Institute.

Assor, Devynta Sari. 2015. Analisis

Produktivitas Lahan Sawah Dengan Citra Foto Vertikal Dengan Platform Uav.Skripsi. Universitas Hasanuddin: Makassar.

Badan Ketahanan Pangan dan Penyuluh
Pertanian Aceh. 2009. Budidaya

Tanaman Padi. Sumatera Utara: Aceh.

Badan Penelitian dan Pengembangan Pertanian, 2016. Budidaya Tanaman Padi. Sumatera Utara: Aceh.

CAB International. 2004. Crop Protection Compendium. Wallingford, UK: CAB (Commonwealth Agricultural Bureau) International. Disajikan dalam compact disc.

Darmawan, Arief. 2012. "Pembangunan Model Hyperspectral Untuk Estimasih Produktivitas Vegetasi Padi Berdasarkan Metode Derivatif Regresi Linear". Institut Teknologi Sepuluh Nopember. Surabaya.

Das D.K, Pradhan. S, Sehgal. V.K, Sahoo. R.N, Gupta. V.K, and Singh. R. 2013. Spectral Reflectance Characteristics Of Healthy and Yellow Mosaic Virus Infected Soybean (Glycine max L.) Leaves In a Semiarid Environment. Journal Of Agrometeorology 15, 3638.

Kartohardjono, Arifin, Denan Kertoseputro, dan Tatang Suryana.Hama Padi Potensial dan Pengendaliannya. 2009. Balai Besar Penelitian Tanaman Padi (BB Padi): Subang.

Naibibi, A. I, Baily Brian, Heakey. R.G, and Collier Peter. 2014. Changing Vegetation Patterns In Yobe State Nigeria : An Analysis Of The Rates of Change, Potential Causes and The Implications for Sustainable Resource Management. International Journal of Geosciences , 50-62.

Novianty, Inna. 2008. Analisa Spektroskopi Reflektans Vis-Nir Untuk Mengetahui Proses Pematangan Buah Stroberi.Skripsi. Fakultas Matematika dan Ilmu Pengetahuan Alam: Bogor.

Sanjaya, Hartono. 2012. Jurnal Sains dan

Teknologi Indonesia. Volume 14, No,

3. Biro Umum dan Humas Badan Pengkajian dan Penerapan Teknologi: Jakarta

Sinadia, Bayu S. 2015. StudiKondisi Tanaman Kakao Di Kabupaten 
Mamuju Berdasarkan Sifat Spektral Menggunakan Citra Landsat 8 Tm. Skripsi. Universitas Hasanuddin:

Makassar.

Siregar, Amalia Zuliyanti. 2007. Hama-

Hama Tanaman Padi. Universitas

Sumatra Utara: Medan.

Susiana, Dodi dan Elfa Diasmara.2008.

Analisis Indeks Vegetasi

menggunakan Data Satelit

NOAA/AVHRR dan TERRA/AQUA-

$M O D I S$. Universitas Indonesia:

Depok.

Suhaimi, 2015.Studi Tentang Kondisi

Cekaman Air Bibit Tanaman Kakao

(Theobroma Cacao L) Dan

Hubungannya Dengan Reflektansi

Tanaman.Skripsi. Universitas

Hasanuddin: Makassar.

Suryanto, F. 2006.Perkembangan Dan

Pemanfaatan Pesawat Terbang Tanpa

Awak (PTTA) Dan Kesiapan Personil

Pendukungnya. Puslitbang Iptekhan

Balitbang Dephan. Buletin Litbang

Pertahanan Indonesia STT No. 2289

Vol 9 No. 16.

Syam, Mahyuddin, Suparyono, Hermanto, dan Diah Wurjandari S. 2011.

Masalah Lapangan Hama Penyakit

Hara Pada Padi. Pusat Penyuluhan

Pertanian: Jakarta.

Tanriverdi. C, KSU, Fakultesi. Z, Bolumu.

T.Y.V.S, and Kahramanmaras. 2006.

A Review of Remote Sensing and

Vegetation Indices in Precision

Farming. Journal Of Science and

Engineering, 69-76.

Wahyunto, Widagdo dan Bambang

Heryanto. 2006. Prediction on Low-

Land Rice Productivity Using Satellite

Remote Sensing Analysis. Vol, 15.

Peneliti Balai Besar Litbang

Sumberdaya Lahan Pertanian (BB

Padi): Subang.

Yulianto, Achmad dan Agus Muhammad

Hatta. 2012. Rancang Bangun

Spektrometer Menggunakan Prisma

Dan Webcam. Institute Teknologi

Sepuluh Nopember: Surabaya. 